\title{
Viral Load as a Predictor of Severity in Crimean-Congo Hemorrhagic
}

\section{Fever}

\author{
Maliheh Metanat, ${ }^{1}$ Batool Sharifi Mood, ${ }_{1}^{1}$ Masoud Salehi, ${ }^{1,}$ Alireza Ansari Moghaddam, ${ }^{2}$ Mohammad \\ Rakhshani, ${ }^{1}$ and Nahid Sepehri $\operatorname{Rad}^{1}$ \\ ${ }^{1}$ Infectious Diseases and Tropical Medicine Research Center, Zahedan University of Medical Sciences, Zahedan, IR Iran \\ ${ }^{2}$ Health Promotion Research Center, Zahedan University of Medical Sciences, Zahedan, IR Iran \\ "Corresponding author: Masoud Salehi, Infectious Diseases and Tropical Medicine Research Center, Zahedan University of Medical Sciences, Zahedan, IR Iran. Tel: \\ +98-54332281012, Fax: +98-5433236722, E-mail: shahsetan@yahoo.com \\ Received 2016 May 10; Revised 2016 October 01; Accepted 2016 October 05.
}

\begin{abstract}
Background: Crimean-Congo hemorrhagic fever (CCHF) is an endemic disease in south eastern of Iran, especially in Sistan and Baluchestan province. CCHF is a potentially fatal disease. Many factors are suggested for the prediction of severity in this disease. Objectives: In this study, the viral load in patients admitted to Boo-Ali hospital was determined and the association between viral load and disease severity was evaluated based on DIC severity score in patients with CCHF.

Methods: In this analytical cross-sectional study, we studied patients with confirmed CCHF who were admitted to Boo-Ali hospital, Zahedan, from September 2012 to March 2014. The patients were divided into two groups based on DIC severity score. Then, the viral load in the patients was measured by using RNA as a template for RT-PCR (QIAgene OneStep SYBR GREEN qRT-PCR smart mix) and finally, the two groups were compared. The results were analyzed using SPSS 20.0 (SPSS Inc.). To investigate the correlation between viral load and disease severity, and also to find the viral load differentiating mild cases from severe cases, ROC curve, Mann-Whitney $\mathrm{U}$ test, and Independent t-test were used.

Results: The total number of patients with confirmed CCHF under the subject of study was 37 (84\% male and 16\% female) in age range of 17 to 58 years $(31.1 \pm 12.2)$. The mean viral loads on the first and fifth days of admission were $1.3 \times 10^{6}$ and $3.7 \times 10^{5} \mathrm{copies} / \mathrm{mL}$, respectively. After grouping patients based on DIC severity, the mean viral load on the first day of admission was $3.2 \times 10^{5} \mathrm{copies} / \mathrm{mL}$ in the mild CCHF group and $4.3 \times 10^{6}$ copies $/ \mathrm{m}$ in the severe CCHF group. The viral load had a direct correlation with CCHF severity $(\mathrm{P} \leq 0.001)$. Serum viral load that differentiated between mild and severe cases of CCHF was determined as $8.6 \times 10^{5} \mathrm{copies} / \mathrm{mL}$ with sensitivity of $100 \%$, specificity of $92 \%$, positive predictive value of $82 \%$, and negative predictive value of $100 \%$.

Conclusions: The viral load in patients who suffer from CCHF has a direct significant correlation with disease severity. Viral load above $8.6 \times 10^{5}$ copies $/ \mathrm{mL}$ on the first day of admission is a predictor of severe CCHF.
\end{abstract}

Keywords: Crimean-Congo Hemorrhagic Fever Virus, Disseminated Intravascular Coagulation, Real-Time Polymerase Chain Reaction

\section{Background}

Crimean-Congo hemorrhagic fever (CCHF) is an acute viral disease that affects various organs in the body and is diagnosed with different symptoms such as vast ecchymosis, visceral bleeding, and impaired liver function. CCHF is caused by infection with a tick-borne virus (Nairovirus) in the family Bunyaviridae. The CCHF virus can cause a severe disease with death rates ranging between 30 and 80 percent $(1,2)$. Patient death occurs due to hypovolemic shock caused by severe bleeding or disseminated intravascular coagulation disorder (DIC) (1,3). Chumakov et al. (1970) (4) first identified CCHFV in $45 \%$ sheep sera that were sent from a Tehran abattoir to Moscow; however, the first human infection was not diagnosed until 1999. The disease incidence eventually grew in several provinces of Iran and the mortality polls reached 26.5 percent (2). From June 1999 to February 2011, Sistan and Baluchestan Province, in Southeast Iran, had the highest prevalence of CCHF (5). Based on research carried out in neighboring countries, one out of five cases diagnosed with CCHF normally leads to death. Middle Eastern viruses have higher intensity compared to the African viruses. The disease incidence is much higher in Pakistan and India. In recent years, the smuggling of livestock from the Eastern borders of Iran, i.e. Afghanistan and Pakistan borders, has increased the disease incidence in the neighboring provinces in Iran (6).

The disease pathogenesis could be related to soluble mediators and immune responses that lead to the direct destruction of vascular systems and parenchymal cells of target organs (7-9). The important factors related to mortality during the first five days of disease are mainly men-

Copyright ( ) 2016, Infectious Diseases and Tropical Medicine Research Center. This is an open-access article distributed under the terms of the Creative Commons Attribution-NonCommercial 4.0 International License (http://creativecommons.org/licenses/by-nc/4.0/) which permits copy and redistribute the material just in noncommercial usages, provided the original work is properly cited. 
tioned as platelet count less than $20000 / \mathrm{mm}^{3}$, ALT $\geq 900$ $\mathrm{U} / \mathrm{L}, \mathrm{AST} \geq 700 \mathrm{U} / \mathrm{L}$, PTT $\geq 60 \mathrm{sec}$, and fibrinogen count less than or equal to $110 \mathrm{mg} / \mathrm{dL}$ (10). In a study, it has been suggested the level of $1060 \mathrm{ng} / \mathrm{dL}$ ferritin serum (sensitivity of $78.9 \%$ and specificity of $87 \%$ ) in order to differentiate between severe and non-severe cases based on the DIC index (11). In most studies, the coagulopathy (clotting disorders) parameters in patients with CCHF and its correlation with disease severity and mortality have been proven $(11,12)$. In a study conducted by Mardani et al. (13), it was shown that patients stricken by low platelets, in particular those with platelets lower than $50000 / \mathrm{mm}^{3}$, are prone to high mortality rates. Patient death occurs due to hypovolemic shock caused by severe bleeding, infection, or disseminated intravascular coagulation disorder (DIC) $(9,13)$. Based on the clinical pathology of the disease, one of the main parameters proposed for CCHF intensity is the DIC severity that occurs amid CCHF disease (11). Furthermore, Cevik et al. (2008) (14) have suggested that platelet counts lower than 20000 per $\mathrm{mm}^{3}$, PTT $\geq 60 \mathrm{sec}$, melena presence, and decreased conscious level are related to the mortality of the CCHF disease (12). In addition, Ergunol et al. indicated platelet counts less than $20000 / \mathrm{mm}^{3}$, ALT $\geq 900$ $\mathrm{U} / \mathrm{L}, \mathrm{AST} \geq 700 \mathrm{U} / \mathrm{L}, \mathrm{PTT} \geq 60 \mathrm{sec}$, and fibrinogen count less than or equal to $110 \mathrm{mg} / \mathrm{dL}$ as the mortality parameters during the first five days of disease occurrence. A few studies have evaluated the role of viral load in disease intensity.

\section{Objectives}

Since the disease is endemic in Sistan and Baluchestan province, Iran, a comparison study regarding viral loads in CCHF patients was conducted to determine whether or not viral load is a predictor of disease severity in CCHF patients.

\section{Methods}

The current study was an analytical-prospective research. All probable patients admitted to Boo-Ali hospital (Zahedan, Iran) that were positively diagnosed with CCHF using serologic and PCR methods included in the study from September 2012 to March 2014. Patients with known malignant disease or diagnosed with other hematological disorders, and those who had been given antiviral, blood, or other blood products during their admittance to hospital were excluded from the study. Patients who were not interested in participation were also excluded. The data including demographic information such as age, sex, paraclinical findings, and information regarding recent disease occurrence were collected through a designed questionnaire. The blood samples (two milliliters) were collected from patients on the first and fifth days of admission to hospital. The virus RNA was extracted from plasma using High Pure Viral RNA Kit (Roche Diagnostics). The viral load was measured using RNA as a template for RT-PCR(QIAgene OneStep SYBR GREEN qRT-PCR smart mix). The values for platelet count, PT, PTT, INR, D-DIMER, and patient's fibrinogen were recorded in the questionnaire. Next, the patients were divided into two groups of severe and non-severe viral load based on DIC severity criteria. The DIC severity scoring was based on the International society on thrombosis and haemostasis (ISTH) $(11,15)$.

\begin{tabular}{|c|c|}
\hline & Score \\
\hline \multicolumn{2}{|l|}{ Platelet count } \\
\hline$>100000 / \mathrm{mm}^{3}$ & 0 \\
\hline $50000-100000 / \mathrm{mm}^{3}$ & 1 \\
\hline$<50000 / \mathrm{mm}^{3}$ & 2 \\
\hline \multicolumn{2}{|l|}{ D-dimer } \\
\hline $0.5-1 \mu \mathrm{g} / \mathrm{mL}$ & 0 \\
\hline $1-3 \mu \mathrm{g} / \mathrm{mL}$ & 2 \\
\hline$>=3 \mu \mathrm{g} / \mathrm{mL}$ & 3 \\
\hline \multicolumn{2}{|l|}{ Fibrinogen } \\
\hline$>=100 \mathrm{mg} / \mathrm{dL}$ & 0 \\
\hline$<100 \mathrm{mg} / \mathrm{dL}$ & 1 \\
\hline \multicolumn{2}{|l|}{ PT rising } \\
\hline$<3 \mathrm{sec}$ & 0 \\
\hline $3-6 \mathrm{sec}$ & 1 \\
\hline$>6 \mathrm{sec}$ & 2 \\
\hline
\end{tabular}

Descriptive statistics were used to present the data and various non-parametric tests such as Mann-Whitney U (2 samples), T-test, and ROC Curve were used to analyze the data. The significance level was set at $\mathrm{P} \leq 0.05$.

\section{Results}

The total number of patients with suspected CCHF were 51 from whom, two cases were diagnosed with hematologic malignancy and Rheumatic diseases and consequently were excluded from the research. In addition, 12 other patients were excluded due to lack of confirmation for CCHF disease. The mean age of the remaining 37 patients ( $84 \%$ male, and $16 \%$ female) was $31.1 \pm 12.2$ years. Disease severity was determined based on DIC scoring system. According to the results of viral load on the first day of admission, 27 patients (72\%) were listed in the mild CCHF group and 10 patients (28\%) in the severe CCHF group. However, the results on the fifth day of admission listed 31(83\%) 
in the mild CCHF group and $6(17 \%)$ in the severe CCHF group. The monitoring of the disease showed that $92 \%$ (n $=34)$ of the patients healed while the remaining $(8 \%, \mathrm{n}=3)$ died due to CCHF.

4.1. Determination of viral load on the first and fifth days of admission in CCHF patients

The mean viral load in blood test samples of 34 patients (3 blood samples excluded due to poor quality) was $1.3 \times$ $10^{6}$ copies/mL on the first day of admission. The lowest and highest viral load values on the first day of admission were $4 \times 10^{3}$ and $7.9 \times 10^{7}$ copies $/ \mathrm{mL}$, respectively. On the fifth day, the mean viral load was $3.7 \times 10^{5}$ copies/mL with the lowest and highest values of zero and $3.7 \times 10^{6}$ copies $/ \mathrm{mL}$, respectively. It should be mentioned that only 24 samples were collected on the fifth day due to dissatisfaction of patients with further sampling or patients' early discharge.

4.2. Viral Load Determination in Mild CCHF Patients Based on DIC Score

The mean viral load obtained for mild CCHF patients was $3.2 \times 10^{5}$ and $1.5 \times 10^{5} \mathrm{copy} / \mathrm{mL}$ on the first and fifth days, respectively. The lowest and highest viral load values for these patients on the first day were $4 \times 10^{4}$ and $1.8 \times 10^{5}$ copy $/ \mathrm{mL}$, respectively. These values were zero and $4.8 \times 10^{5}$ copies/mL on the fifth day, respectively.

\subsection{Viral Load Determination in Severe CCHF Patients Based on DIC Score}

The mean viral load obtained for severe CCHF patients was $4.3 \times 10^{6}$ and $1 \times 10^{5}$ copies/mL on the first day and fifth day of admission, respectively. The lowest and the highest viral load values for these patients on the first day was 9.8 $\times 10^{5}$ and $7.9 \times 10^{6}$ copies $/ \mathrm{mL}$, respectively. These values were $2.1 \times 10^{5}$ and $3.7 \times 10^{5}$ copies/mL on the fifth day, respectively.

4.4. Comparison of Viral Load in CCHF Patients With Various DIC Severities (Mild or Severe)

The Mann-Whitney statistical test showed a significant difference in viral load between two groups with various DIC severities (Table 2).

4.5. Determination of "Sensitivity", "Specificity", "Positive Predictive Value", and "Negative Predictive Value" Related To Viral Load Level as Predictor of Disease Severity in CCHF Patients

Based on the ROC curves, the serum viral load level that differentiated between mild and severe cases of CCHF on the first day of admission was $8.6 \times 10^{5}$ copies $/ \mathrm{mL}$ with sensitivity of $100 \%$, specificity of $92 \%$, positive predictive value of $82 \%$, and negative predictive value of $100 \%$. The corresponding values on the fifth day were $3.7 \times 10^{5}$ copies $/ \mathrm{mL}$, $83 \%, 84 \%, 62.5 \%$, and $94.1 \%$, respectively.

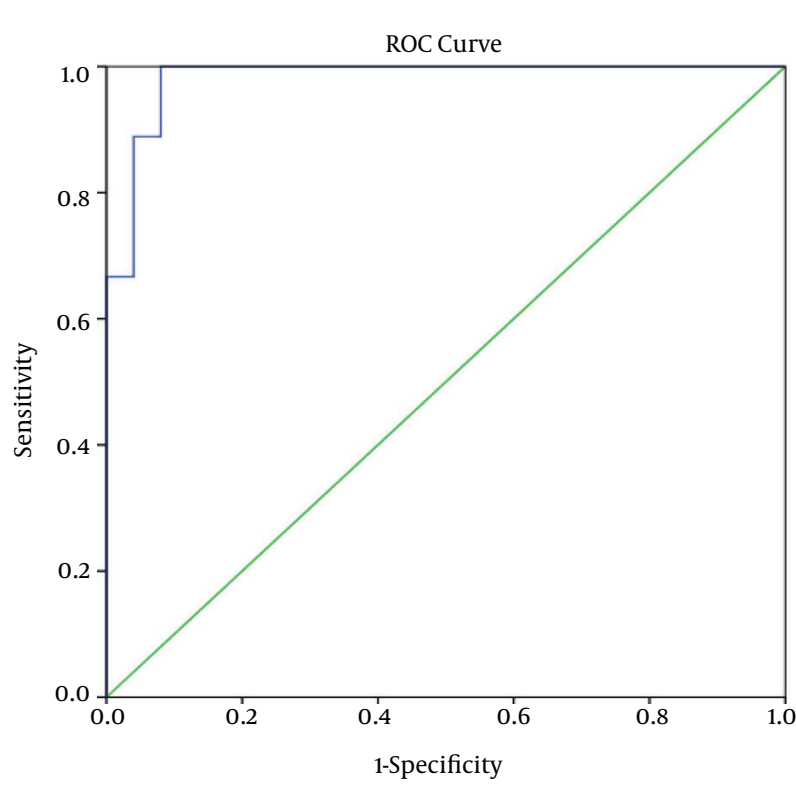

Figure 1. ROC curve for Serum Viral Load on the First Day

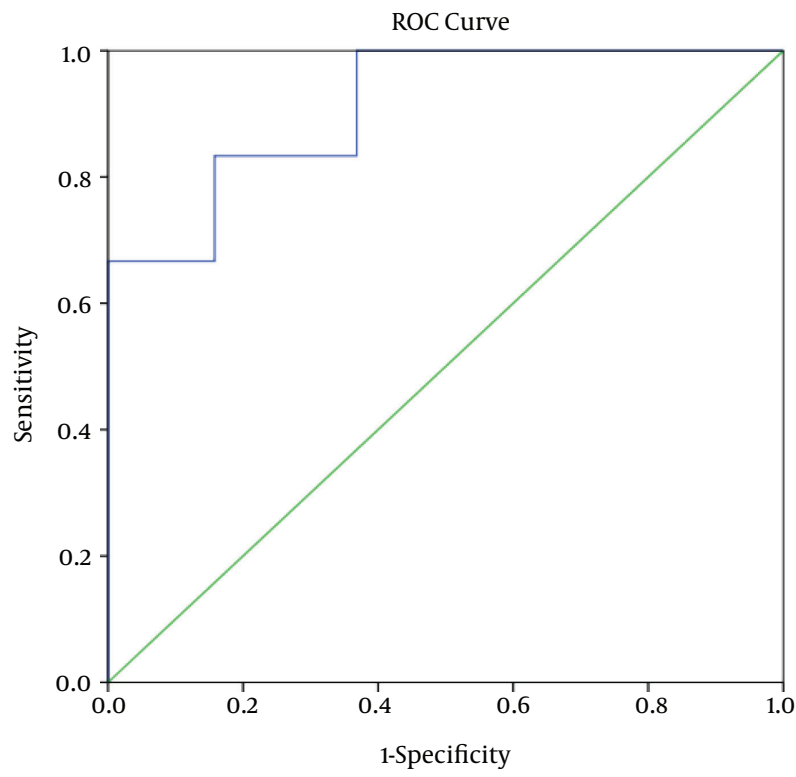

Figure 2. ROC Curve for Serum Viral Load on the Fifth Day

\section{Discussion}

In the present study, patients were divided into two groups of severe and mild CCHF based on DIC score and then, the viral load in the two groups were compared. The results indicated the mean serum viral load was $3.2 \times 10^{5}$ copies $/ \mathrm{mL}$ in the mild CCHF group and $4.3 \times 10^{6}$ copies $/ \mathrm{ml}$ 
Table 2. Comparison of Viral Load in CCHF Patients With Various DIC Severities on the First Day and Fifth Day of Admission

\begin{tabular}{l|c|c|c|c|c}
\hline Disease Severity & Frequency & Mean $($ Copies/mL) & SD & Median & PValue \\
\cline { 1 - 4 } The first day: Mild & 27 & $3.2 \times 10^{5}$ & $4.2 \times 10^{5}$ & $1 \times 10^{5}$ & 0.0001 \\
\hline The first day: Severe & 10 & $4.3 \times 10^{6}$ & $2.4 \times 10^{6}$ & $5.4 \times 10^{6}$ & 0.001 \\
\hline The first day: Mild & 19 & $1.5 \times 10^{5}$ & $1.2 \times 10^{5}$ & $7.2 \times 10^{4}$ & \\
\hline The first day: Severe & 6 & $1 \times 10^{6}$ & $1.3 \times 10^{6}$ & $6 \times 10^{5}$ & \\
\hline
\end{tabular}

in the severe CCHF group. The Mann-Whitney test showed a significant difference in serum viral load values between the groups $(\mathrm{P} \leq 0.001)$. In addition, cut-off point of viral load level on the first day of admission was $8.6 \times 10^{5}$ copies/mL with sensitivity, specificity, positive predictive value, and negative predictive values of $100 \%, 92 \%, 82 \%$, and $100 \%$, respectively. The cut-off point of serum viral load on the fifth day was $3.7 \times 10^{5}$ copies/mL; and sensitivity, specificity, positive predictive value, and negative predictive value were $83 \%, 84 \%, 62.5 \%$, and $94.1 \%$, respectively. Some studies have suggested a higher viral load as an indicator for severe disease intensity. For instance, Cevik et al. (16) have indicated a viral load value higher than $1 \times$ $10^{9}$ copies/mL as predictor of a fatal outcome with positive predictive value of $80 \%$, sensitivity of $88.9 \%$, and specificity of $92.6 \%$. Furthermore, the results of their study showed that the mean peak titer in patients with a fatal outcome was $7.1 \times 10^{9}$ copies/mL, whereas in patients with a nonfatal outcome, the mean titer was $4.1 \times 10^{6}$ copies $/ \mathrm{mL}$. In another study conducted in Kosovo (by Duh et al. (17)), patients were divided into three different groups of fatal, severe, and moderate (based on clinical and Para-clinical findings). A viral load higher than $10^{8}$ copies/mL was selected to differentiate between fatal and recovered groups. The mean viral loads in the fatal and recovered groups were $1.78 \times 10^{6}$ and $8.06 \times 10^{6}$ copies/mL, respectively. As mentioned above, the comparison criteria differ from one study to another; for instance in some studies, two groups of patients including patients with recovered and fatal outcomes were compared with each other $(16,17)$. Up to now, various parameters have been proposed to determine disease severity including platelet counts lower than 50000/ $\mathrm{mm}^{3}$, increased levels of PTT, PT, Liver transaminases, muscle enzyme, and viral load levels. However, researchers have a common agreement that severity of DIC, which occurs during CCHF, can be used as a prediction factor for disease severity $(11,15,18)$. In the current study, three cases of fatal outcome occurred with initial platelet counts of 4000,19000 , and $10000 / \mathrm{mm}^{3}$. Their liver enzyme levels (ALT of 1612, 280 and 250; AST of 9197, 240 and 200, respectively) were other indicators of severe disease. A significant difference was observed in viral load, platelet levels, and co- agulation factors such as INR and PT $(\mathrm{P}<0.05)$ that were associated with the severity of the disease. A platelet count under $50000 / \mathrm{mm}^{3}$ was described as fatal indicator by Mardani et al. Also, six different parameters including platelet, D-Dimer, INR, PT, PTT, and fibrinogen were suggested as disease severity indicators by Mehrabi et al. and Hasanoglu et al. $(9,13,19)$.

The current research faced two main limitations. First, the time of admission was different in the patients. Second, some of the patients were discharged earlier or did not further consent to be kept at the hospital or cooperate with our study.

In summary, the results indicated a significant relationship between viral load and disease severity in patients with CCHF. Based on the results, it is highly suggested to measure viral load of admitted patients with suspected CCHF. This would allow admitting patients with high viral load as "high-risk" patients.

\section{Acknowledgments}

The study was financially supported by the vice chancellor for research of Zahedan University of Medical Sciences. The information provided in this study is derived from a thesis approved by the ethics committee under no. 91-1734. Authors of the present study, appreciate all staff of Boo-Ali hospital who assisted us in this study. We are grateful to Mrs. Hajar Jokar, Sedighe Soroush, and Kobra Akbari who helped us with collecting information.

\section{Footnote}

Authors' Contribution: Study concept and design: Maliheh Metanat; acquisition of data: Mohammad Rakhshani and Nahid Sepehri Rad; statistical analysis and interpretation of data: Masoud Salehi and Alireza AnsariMoghaddam; critical revision of the manuscript for important intellectual content: Batool Sharifi Mood. 


\section{References}

1. Sharifi-Mood B, Metanat M, Ghorbani-Vaghei A, Fayyaz-Jahani F, Akrami E. The outcome of patients with Crimean-Congo hemorrhagic fever in Zahedan, southeast of Iran: a comparative study. Arch Iran Med. 2009;12(2):151-3. [PubMed: 19249885].

2. Metanat M, Sharifi-Mood B, Salehi M, Alavi-Naini R. Clinical Outcomes in Crimean-Congo Hemorrhagic Fever: A Five-years Experience in the Treatment of Patients in Oral Ribavirin. Int J Virol. 2006;2:21-4. doi 10.3923/ijv.2006.21.24.

3. Onguru PD, Bodur H, Yilmaz M. Coagulopathy parameters in patients with Crimean- Congo, Hemorrhagic fever and its relation with mortality. J Clin Laboratory Analysis. 2010;24:163-6.

4. Hoogstraal $\mathrm{H}$. The epidemiology of tick-borne Crimean-Congo hemorrhagic fever in Asia, Europe, and Africa. J Med Entomol. 1979;15(4):307-417. [PubMed: 113533].

5. Tabatabaei SM, Hassanzehi A, Pakzad A, Mohammdi M, Madani A. Factors Influencing Crimean-Congo Hemorrhagic Fever Risk Perceptions in the General Population, Southeast Iran. Int J Infect. 2014;1(1):18150. doi:10.17795/iji-18150.

6. Emadi Koochak H, Yalda AR, Haj Abdolbagh M, Sood Bakhsh A. Crimean-Congo Hemorrhagic Fever. Tehran Univ Med J. 2003;61(5):343-58.

7. Sharifi-Mood B, Alavi-Naini R, Metant M. Ten yeatrs after the beginning of the Crimean-Congo Haemorrhagic Fever outbreak in Iran: A promising repor. Iran J Clin Infect Dis. 2009;4(3):189-19.

8. van Eeden PJ, Joubert JR, van de Wal BW, King JB, de Kock A, Groenewald JH. A nosocomial outbreak of Crimean-Congo haemorrhagic fever at Tygerberg Hospital. Part I. Clinical features. S Afr Med J. 1985;68(10):711-7. [PubMed: 4060010].

9. Mehrabi-Tavana A, Chinikar S, Mazaheri V. The seroepidemiological aspects of Crimean-Congo hemorrhagic fever in three healthcare workers: a report from Iran. Arch Iranian Med. 2002;255-8(5):3.

10. Yilmaz G, Koksal I, Topbas M, Yilmaz H, Aksoy F. The effectiveness of routine laboratory findings in determining disease severity in patients with Crimean-Congo hemorrhagic fever: severity prediction criteria. J Clin Virol. 2010;47(4):361-5. doi: 10.1016/j.jcv.2010.01.010. [PubMed: 20149724].

11. Metanat M, Sharifi-Mood B, Tabatabaei M, Sarraf-Shirazi M. Can Serum Ferritin Level Predict Disease Severity in Patients with Crimean-Congo Hemorrhagic Fever?. Eurasian J Med. 2013;45:108-14.

12. Ergonul O, Celikbas A, Baykam N, Eren S, Dokuzoguz B. Analysis of risk-factors among patients with Crimean-Congo haemorrhagic fever virus infection: severity criteria revisited. Clin Microbiol Infect. 2006;12(6):551-4. doi: 10.1111/j.1469-0691.2006.01445.x. [PubMed: 16700704].

13. Mardani M, Keshtkar-Jahromi M. Crimean-Congo hemorrhagic fever. Arch Iran Med. 2007;11(3):204-14.

14. Cevik MA, Erbay A, Bodur H, Gulderen E, Bastug A, Kubar A, et al. Clinical and laboratory features of Crimean-Congo hemorrhagic fever: predictors of fatality. Int J Infect Dis. 2008;12(4):374-9. doi: 10.1016/j.ijid.2007.09.010. [PubMed: 18063402].

15. Bakhtiari K, Meijers JC, de Jonge E, Levi M. Prospective validation of the International Society of Thrombosis and Haemostasis scoring system for disseminated intravascular coagulation. Crit Care Med. 2004;32(12):2416-21. doi: 10.1097/01.CCM.0000147769.07699.E3.

16. Cevik MA, Erbay A, Bodur H, Eren SS, Akinci E, Sener K, et al. Viral load as a predictor of outcome in Crimean-Congo hemorrhagic fever. Clin Infect Dis. 2007;45(7):96-100. doi:10.1086/521244. [PubMed:17806044].

17. Duh D, Saksida A, Petrovec M, Ahmeti S, Dedushaj I, Panning M, et al. Viral load as predictor of Crimean-Congo hemorrhagic fever outcome. Emerg Infect Dis. 2007;13(11):1769-72. doi:10.3201/eid1311.070222. [PubMed: 18217568].

18. Ergonul O, Tuncbilek S, Baykam N, Celikbas A, Dokuzoguz B. Evaluation of serum levels of interleukin (IL)-6, IL-10, and tumor necrosis factor-alpha in patients with Crimean-Congo hemorrhagic fever. J Infect Dis. 2006;193(7):941-4. doi:10.1086/500836. [PubMed: 16518755].

19. Hasanoglu I, Guner R, Carhan A, Kocak Tufan Z, Yagci-Caglayik $\mathrm{D}$, Guven T, et al. Crucial parameter of the outcome in Crimean Congo hemorrhagic fever: Viral load. J Clin Virol. 2016:42-6. doi: 10.1016/j.jcv.2015.12.006. 